\title{
COMPARATIVE OF CONVENTIONAL MARKETING AND SHARIA MARKETING AGAINST MASLAHAH WITH CUSTOMER SATISFACTION AS INTERVENING AT CUSTOMER SUPER MARKET IN BATAM CITY
}

\author{
ChablullahWibisono \\ Faculty of Economics, University of Batam, Indonesia \\ Chablullah.wibisono@univbatam.ac.id \\ Correspondent email:chablullahwibisono@gmail.com
}

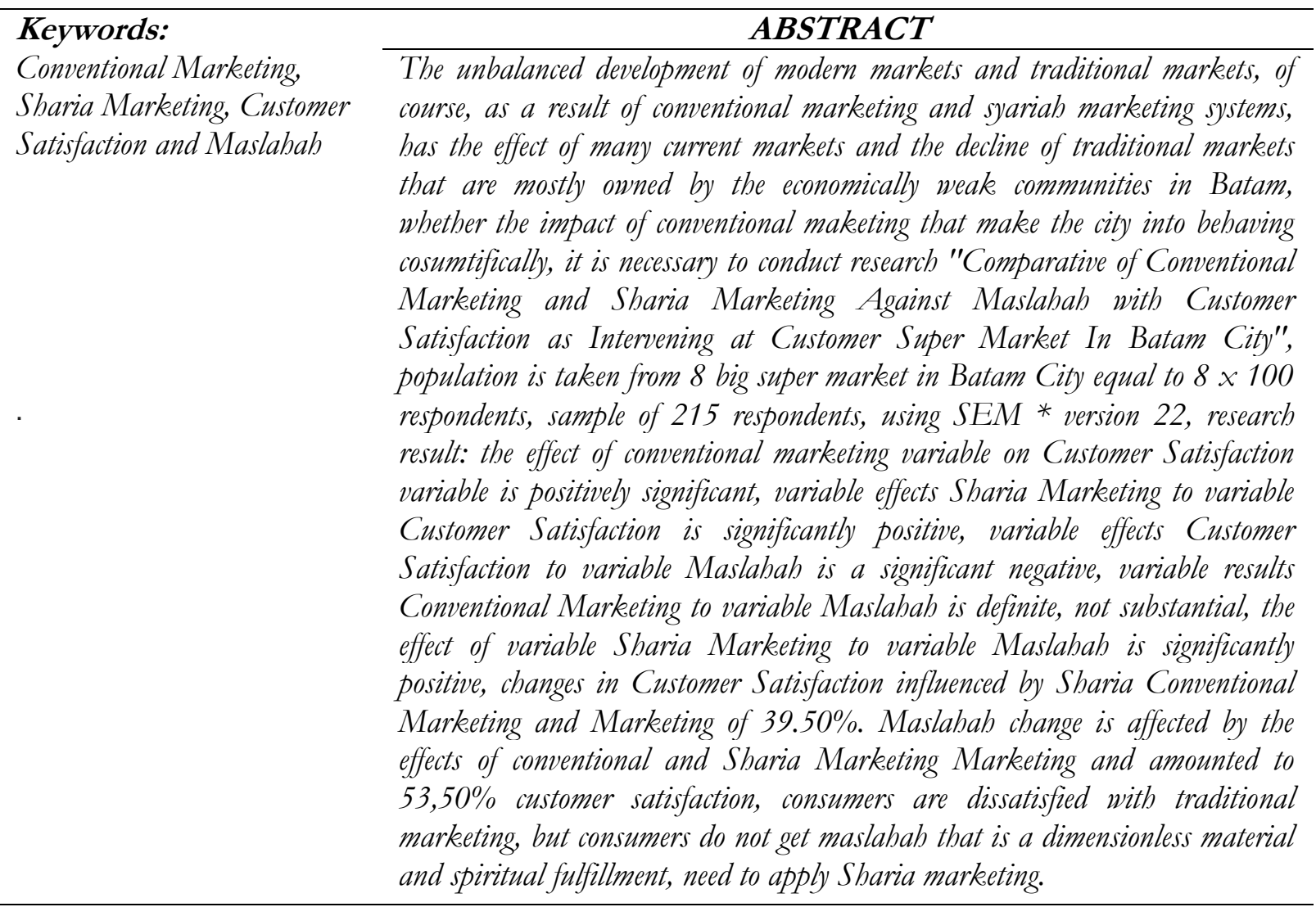

\section{BACKGROUND}

Mu'amallat demand patterns in motivation to work and produce the indicator variables, the need for secondary, primary needs, when Compared with the model of needs Maslow secular paradigm, there is a Similar pattern in human nature, but there are differences on how to approach and motives. The difference between modern economics with Islamic economics lies in the consumption pattern in his approach to meeting the needs of a person. Islam does not Recognize the purely materialistic craze of modern consumption patterns, but Islam Teaches a balance between material and spiritual.

Observing the development and growth of modern markets, the which are not comparable with traditional markets and local markets, has Described the tendency of secondary requirement (psychology) is dominant, and has been proven by surveys Consumption of the Central Bureau of Statistics, the study Showed spending to meet the needs of secondary (psychological) years in 2017 amounted to $62.56 \%$, while for the primary needs of $37.44 \%$. The command to meet the needs of secondary and primary needs exist in the newspapers, but everything was to improve performance to religious (righteous deeds) is not for the sheer 
satisfaction. Meeting the needs of secondary justified by Islam but Aimed to enhance work performance and should not ignore the needs of primary (essential).

Islamic teachings are exemplified by Prophet Muhammad concluded that the necessities of life for every member of society should be available. Basic needs such as food, clothing and shelter, the which are Necessary for the improvement of work efficiency is called "appropriate requirements" for religious improve work performance. The imbalance in the development of modern markets and traditional markets, indeed as a result of the marketing system of conventional and system marketing Sharia, but Whether with many current markets (supermarkets) in Batam will have the effect of maslahah, and Whether traditional markets with Sharia would have the impact of maslahah through consumer satisfaction.

\section{THEORETICAL BASIS}

\section{a. Conventional Marketing Theory}

Kotler and Keller (2008: 5) Marketing is an organizational function and a set of processes for creating, communicating, and delivering value to customers and for managing customer relationships in ways that benefit the organization and its stakeholders. According to Boyd et al. (2000: 4) Marketing is a social process that involves essential activities that allow individuals and companies to get what they need and want through exchanges with the parties and to develop the exchange relationship. While the definition of marketing by Stanton (1996: 7-8) marketing is a system of total business activity designed to Determine the price, promote and distribute goods and services that can satisfy the desire either to consumers or potential consumers this time, of the above definition can be concluded that the Conclusions taken in the field of marketing, should be addressed to Determine the product and the market, price, and promotion, in order to give satisfaction to the consumer. From the definitions above, marketing Gives the sense that marketing is not only activities that occur before the product begins and is a system of events that are interconnected from planning, pricing, promoting and distributing goods and services to consumers.

American Marketing Association (AMA) marketing management defines as follows: "The marketing management as the art and science of choosing the target markets and getting, keeping and growing customers to create, deliver, and communicating superior customer value." According to the above definition, it can be said that marketing management is a process that begins the process of planning, directing, and controlling product or service, pricing, distribution, and promotion with the purpose of assisting the organization in Achieving its goals. (Hose, 2013: 72) The marketing mix is the device marketing tool used by companies to pursue its objectives ". Tus, it can be concluded that the marketing mix is a device that consists of product, price, promotion, and distribution, in the which will Determine the level of marketing success and all of it is Aimed to Obtain the desired response from the target market. (Kotler and Keller, 2007).

The intensity of competition in the market forcing companies to pursue high product adaptation to Achieve a competitive advantage over competitors, since the adjustment of products to Broaden the base of the local market and enhanced for specific regional preferences. More and more consumers have an alternative and very careful in Determining the decision to purchase to Consider Reviews These factors needs, product excellence, service and price comparisons before Deciding to buy. Of Reviews, These factors, the superiority of the products included in the primary consideration before buying. The competitive advantage of a product is one of the determinants of success of new products, where the product's success is measured by parameters number of product sales. (Tjiptono, 2008).

Price is an amount of money (plus a few products) are required to Obtain a combination of products and services. From the above definition, it can be seen that the price 
paid by the buyer already includes services provided by the seller. Many companies hold approach to pricing based on the objectives to be Achieved. The purpose can be to increase sales, maintain market share, maintaining price stability, Achieve maximum profit and so on. (Engel, J; R Blackwell, 2004).

The location or place Often will Determine the success of the company, Because it is closely related to the area of a company's potential market. Also, the location also Affect the dimensions of strategies such as flexibility, competitive, positioning, and focus. Flexibility, a given area, is a measure of the extent to the which a company can react to changes in the economic situation. Site selection decision about a long-term commitment to aspects that are capital-intensive, the company really should Consider and select locations that are responsive to the financial condition, demography, culture, and competition in the future. (Hose, 2013: 73).

Promotion is a form of marketing communication is a marketing activity that seeks to disseminate information, influence / persuade, and warned target market for the company and its products to be willing to accept purchase, and loyal to the products offered by the company concerned. (Tjiptono, 2007: 209-210).

\section{b. Marketing Sharia Theory}

Prophet Muhammad Gave the example profession besides being Apostles but Also Be Traders, where one of the functions of the trade is how to market goods and services, so that customers feel satisfied and not feel disadvantaged, that the importance of honesty. Allah says:

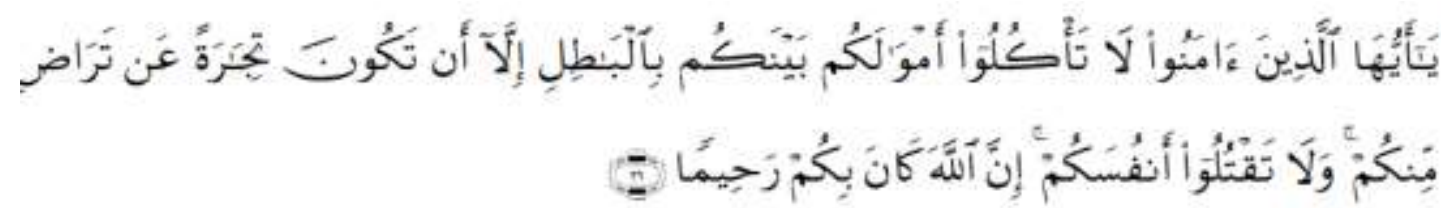

O ye who believe, do not eat each other neighbor's property by way of vanity, except by way of commerce that goes with the same love-love between you. And do not kill yourselves; surely Allah is Merciful to you. (QS. An-Nisa: 29).

To satisfy customers and not disappoint the customers it is Necessary to regulate how the marketing strategy. TheSharia-based marketing strategy that is professionally doing business with the values the which form the base: 1 . Have a spiritual personality (taqwa). 2 . Behave well and sympathetic (sidiq). 3. Serve the customers with a smile and humble (Solemn). 4. Keeping a promise and not cheating (tariff). 5. Honest and trustworthy (al-trust). 6. Do not like prejudice (su'uzhzhann). 7. Do not vilify (backbiting). 8. Do not do bribes (risywah) (Fatimah, 2015: 123-125).

In carrying out Shariah-based marketing cannot be separated from the law of Sharia law itself is called maqashid al-Sharia consists of two words, Madrid and Shari'ah. Said maqashid a form jama' of Mashad meaningful goals and objectives, while Shari'ah had understanding God's laws are set to man to be guided to ATTAIN happiness in this world and the life hereafter. And thus, the maqashid al-Shari'ah means the content of value into law shari'a goal. And thus, the maqashid al-Shari'ahare the objectives to be Achieved from a determination of the law. (Fauzi, 2015: 144)

Wahbah al-Zuhailimaqashidsyariah defines the meanings and purposes that are maintained by the Personality 'legal in all or most laws, or the final destination of the Shari'ah and the secrets were laid by the Personality' at each law. Yusuf Qaradawi 2 according to one of the aims of the Shariab(maqashidSharia) is the presence of justice. This justice in the sense that a 
company does not exploit the consumer and the company made a profitable product for the consumer. So between businesses and consumers could be mutually beneficial (Fauzi, 2015: 144). Socould interpreted that marketing management is based on MAQASHID SHARLA as analysis, planning, implementation and control of programs designed to create, build, andmaintain a favorable exchange with the target market in order to achieve organizational objectives by taking into account fairness between the consumer and the company.

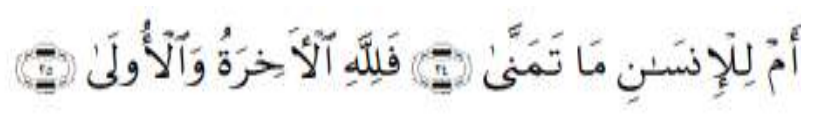

Whether or people will get everything it wanted? (No), then God just for the afterlife and life of the world. (QS. An Najm: 24-25)

Masalahah can be divided into three levels items, namely:

1) Dharuriyat That is the primary beneficiaries, in the which human life is very dependent on him, both aspects diniyah (religious) and practical aspects. So this is something that cannot be left in human life. If it does not exist, human being on earth be destroyed, and life hereafter Become damaged (got the punishment). This is the highest level of beneficiaries. In Islam, these dharuriyat beneficiaries are protected from two sides: first, the realization and embodiment, and secondly, maintaining its sustainability. For example, the first keeping faith with the understanding and perform all religious duties, as well as the second to preserve the spiritual struggle and jihad against the enemies of Islam.

2) Hajiyat The beneficiaries the which are secondary, are required by man for ease of life and Eliminate the Difficulties and narrowness. If he were not there, there would be Difficulties and the prejudice of the implications of not to damage the experience.

3) Tahsiniyat, i.e., beneficiaries who are demands muru'ah (moral), and it was meant for goodness and glory. If he is not there, then not to destroy or make it difficult, for human life. Tabsiniyatbeneficiaries are Necessary as tertiary needs to improve the quality of human life.

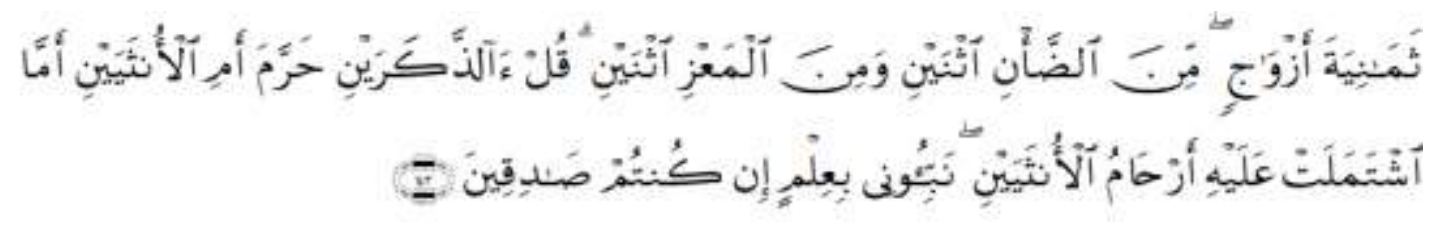

(Ie) The eight animals in pairs, a pair of sheep and a couple of goats. Say: "Are the two lazy to the which God has forbidden or the two females, or that the which exists in the womb of the two females?" Explain to me by knowledge if ye are truthful (QS. Al-An'am: 143). Then the unjust, and like reducing the dose is strictly prohibited by Islam.

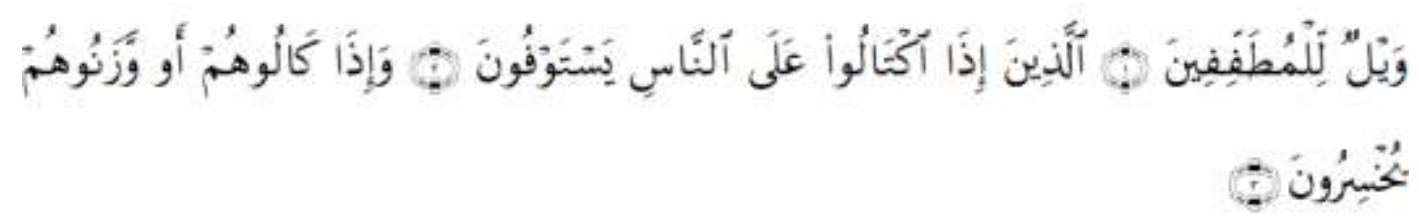

"Woe to Reviews those who cheat, (i.e.) Reviews those who, when receiving the dose from others demand full, and when they measure or weigh for others, they reduce" (QS. Al Muthaffifiin (1-3). 
The theory of marketing Sharia Teaches that nature of promotion and advertising should not be doing a lie. In a hadith, the Prophet Muhammad said: "If the item was damaged say broken, do not you hide. If the item was cheap, do you say expensive? If this stuff says ugly, do not you say good" (HR. Tirmidhi). The hadith Also supported hadith narrated by IbnMajah and IbnHanbal, "not permissible for a Muslim to sell the defective goods, UNLESS he told her, "Furthermore, in a hadith that Mentioned"Traders are honest and trustworthy will be with the Prophets, the people are frank and the martyrs"(HR. Tarmidzi and Ibn Majah)

\section{c. Theory of Customer Satisfaction}

In conventional marketing approach, marketing strategy formulation to emphasize compelling narrative ads and Often use words exploitative and exaggerated than the reality, the which plunge marketing Eventually rigid standards, and dried on innovation. Unlike in experiential marketing approach that put more emphasis on customer satisfaction in enjoying the product through experience Possessed. This approach emphasizes the provision of comfort with some indicators such as sense, feel, think, act and relate. From this experience, the expected customer/client satisfied that would give a reasonable conclusion with a multiplier effect in the form of customer loyalty/customer. Islam Teaches provide the best included in serving customers,

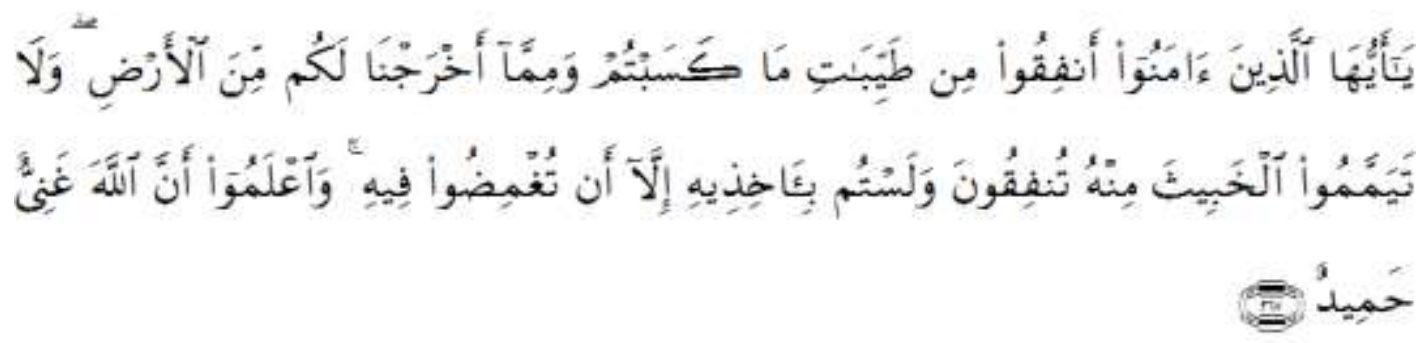

O ye who believe! Spend (in the way of Allah) a part of your good works and part of what We bring forth from the earth unto you. And do not choose the evil and then you spend it, but you do not want to take it but by squinting at it. And know that Allah is Rich and Praiseworthy. (Quran Surah Al Baqarah: 267) in Ministry of Religious, 2016).

Meaningful service quality delivers superior value to the firm. To create a substantial barrier needed Servqual strategy with adequate competence. Quality of service can be interpreted as a sign that customers will be more loyal, using more programs Servqual, and WoldOf Mouth for the company. Therefore, the application of quality of service is one of the critical success factors for many companies. The ability to Increase application quality of service is a matter of life and death for the company. Implementation of service quality for the group plays an essential role in the creation of customer value. Based on the opinions Sivadas and Prewitt (2000) service quality is a customer assessment of the cost of a superior or perfection of a product (service) of the usefulness or benefits received (perceived) customers on the basis of a comparison of what is given (customers) and what is acceptable (customer).

In relationship marketing literature, especially the concept of quality of service in the roommate's long-term basis, the critical relationship between the company and customers as well as customer value is formed and lasted a long-term basis is Servqual and customer satisfaction. Quality of service is the beginning of a measurement of the relationship and influence between service quality and customer satisfaction. Especially the concept of quality of service in the roommate's long-term basis, the critical relationship between the company and customers as well as customer value is formed and lasted a long-term basis is Servqual and customer satisfaction. Quality of service is the beginning of a measurement of the relationship 
and influence between service quality and customer satisfaction. Especially the concept of quality of service in the roommate's long-term basis, the critical relationship between the company and customers as well as customer value is formed and lasted a long-term basis is Servqual and customer satisfaction. Quality of service is the beginning of a measurement of the relationship and influence between service quality and customer satisfaction. Quality of service is the beginning of an analysis of the relationship and impact between service quality and customer satisfaction. Especially the concept of quality of service in the roommate's longterm basis, the critical relationship between the company and customers as well as customer value is formed and lasted a long-term basis is Servqual and customer satisfaction. Quality of service is the beginning of a measurement of the relationship and influence between service quality and customer satisfaction. Quality of service is the beginning of an analysis of the relationship and impact between service quality and customer satisfaction. Especially the concept of quality of service in the roommate's long-term basis, the critical relationship between the company and customers as well as customer value is formed and lasted a longterm basis is Servqual and customer satisfaction. Quality of service is the beginning of a measurement of the relationship and influence between service quality and customer satisfaction.

Referring to the managerial implications in research where, is Expressly advised on the management engaged in service industries that, if only the administration would seek technical competence and social about what the expectations of customers and customer value, especially on Servqual, it is Certain that the company's performance over the long term will Significantly Increase. This was due, in compliance with the service quality expectations of customers will be the make-customers satisfied, and having happy customers will be loyal is to use the services offered by the company continually. Quality of service above what was expected (expectation) as a customer's expectations from a function in the normative framework and predictable about how high quality of services Provided to customers by the company. Tangible, reliability, responsiveness, and guarantees and empathy as a positive influence on service quality dimensions on customer value, especially in the service industry, it is real, honest, sensitive, and Assurances and understanding are vital to the survival and sustainable enterprises. To win today's customers, companies need to embrace what the business habits and focuses on building and maintaining tangible, reliability, responsiveness, and guarantees and empathy in the quality of service (Chan: 2006)

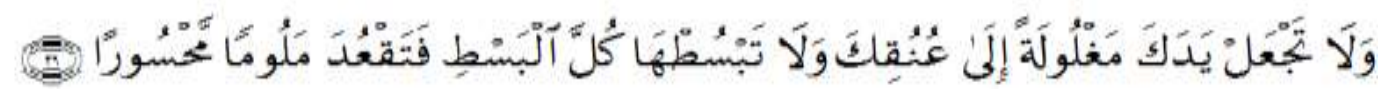

"And do not make your hands chained to your neck and did not give them too much for it, so you Become disgraceful and contrite. (Customer satisfaction)" (Quran Surah Al-Isra: 29) in Ministry of Religious Affairs, (2016).

The company aims to create and keep customers. This means in Achieving success, and businesses must be Able to Ensure the needs and desires of its customers and all of it are reflected in the service performed or produced by the company. The quality of service is sufficient understanding of the business on the client to be Able to create superior value for the customer value continuously. Therefore, qualified companies can be referred to like a company with ability and willingness to identify, analyze, understand and respond to the needs of customers. The quality of service Also helps the group learn that a large part of the technical issues and provide evaluation market segments as possible, the importance of the market and the value of growth (Frankl, 2017: 5) 
AL-MASHRAFIYAH: Jurnal Ekonomi, Keuangan dan Perbankan Syariah Volume 2, Nomor 1 April 2018

\section{d. Theory Maslahah}

Etymologically, meaning al-maslahah can mean goodness, usefulness, appropriateness, feasibility, harmony, decency. Said al-maslahah opposed to al-mafsadah word meaning damage. In terminological maslahah has been given the charge of meaning by some scholars of Usul al-fiqh. Al-Ghazali (d. $505 \mathrm{H}$ ), for example, say that the genuine sense of maslahah is exciting / Realize the benefits or get rid of / avoid harm (jalbmanfa'ah or daf 'madarrah) According to al-Ghazali, who Referred maslahah, within the meaning of terminological -syar'i, is to maintain and Realize the goal of Syara 'in the form of maintaining religion, life, intellect, lineage, and wealth. Confirmed by al-Ghazali, that everything that can guarantee and protect the existence of five things qualified as maslahah; on the Contrary, everything that can Disrupt and destroy the five it is judged as mafsadah; hence, Prevent and Eliminate something that is so qualified as maslahah (Asmawi, 2014: 314).

Maslaha desired destination by al-shari'ah 'within the laws set Him through sacred texts of Sharia (nusûs al-shari'a) in the form of the Qur'an and Hadith. Those goals include six (6) major issues items, namely the protection of religion, the protection of life, protection against reason, protection of offspring, protection against self-respect, and protection of wealth. Maslahah were stratified ie, darûriyyât, hâjiyyât and luxuries. Something that can Ensure the existence of each of the six major issues that are at the level darûriyyâtmaslahah. Something that can provide convenience and support to guarantee the existence of each of the six major issues that are at the level hâjiyyâtmaslahah. Something that can give beauty, perfection,

Maslahabit includes two (2) elements of a coherent and holistic items, namely jalb almanâfi'/ al-masâlibwadar al-mafâsid / al-madârr the which means "making something useful / good or bring benefit / goodness, and Prevent and Eliminate anything negative-destructive or bring damage / harm, in the which case all Werner within the framework of directives of the Qur'an and Hadith. in this case, need to be Considered in terms of the concerns of individual interest / limited (al-maslahah al- khâssah) and public interest / public (al-maslahah al-'amma), and priority is given to public interest/public at large. maslahah contained in nass-nass can be understood by examining the content of the meaning of nass-nass it. Here it should be implemented a step "maslahah interpretation oriented towards nass" (al-Tafsir al-maslabiy li alnusûs) and "application-driven maslahah against nass "(al-tatbîq al-maslabiy li al-nusûs). (Asmawi, 2014: 325).

\section{e. Basic Theory Framework}

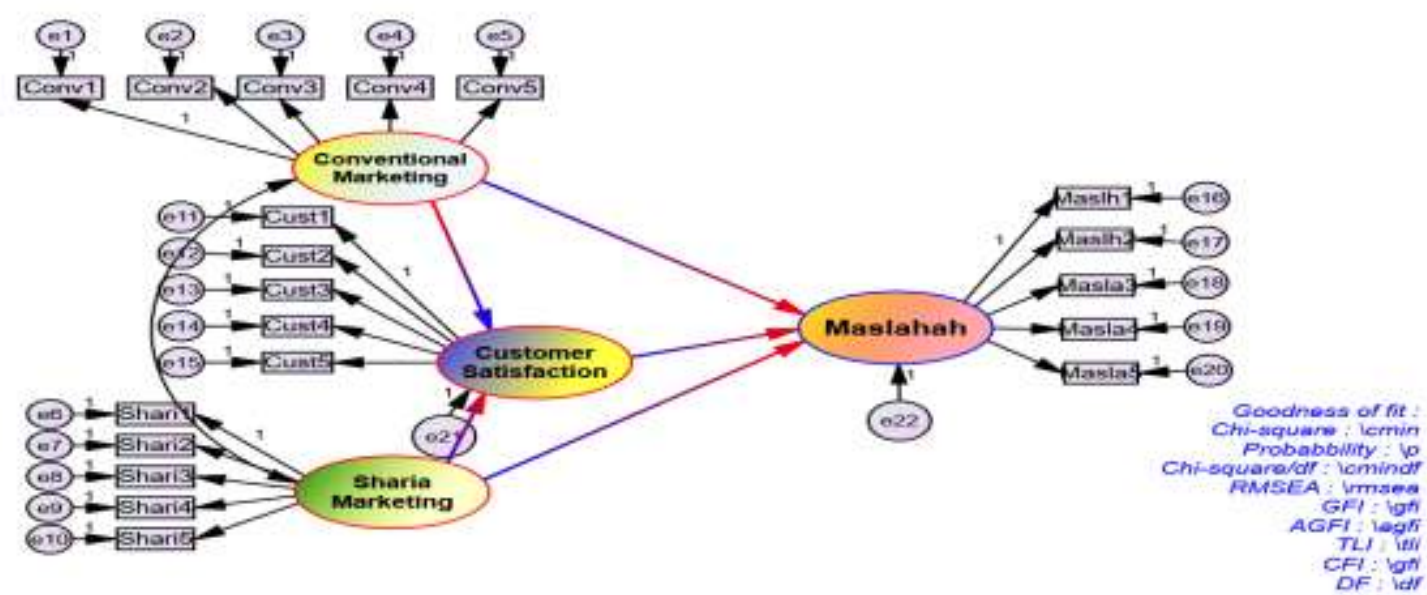

COMPARATIVE OF CONVENTIONAL MARKETING AND SHARIA MARKETING AGAINST MASLAHAH WITH CUSTOMER SATISFACTION AS INTERVENING AT CUSTOMER MALL IN BATAM CITY - INDONESIA

Figure 1. Research models 


\section{a. Population and Sample \\ 1) Population}

\section{RESEARCH METHODS}

The community is a collection of the whole object to be measured in the study (Cooper and Schindler, 2003: 179). The people in this research are all entire street vendors in the Market of Badung, Bali. Therefore, the size of the population in this study is unknown, so the sampling technique used in the category of non-probability sampling. By the specific sample, characteristics are required, are the entire workers, then sampling technique selected non-probability technique is judgmental (purposive). This method is chosen to Ensure that only the samples that have Certain elements that have been established by Researchers who will be taken as samples (Black and Champion, 2001: 264). Dambil population of from 8 Super Market is excellent, in the city of Batam amounted to $8 \times 100$ respondents $=800$ respondents

\section{2) Sample}

The sample is an element of the population selected to represent the population in the research (Cooper and Schindler, 2003: 82). In this study, the sample size adapted to the analysis, the models used is Structural Equation Model (SEM). In this regard, the sample size for SEM used the models estimates the maximum likelihood estimation (MLE) is 100-200 samples (Hair et al., 1998: 605; Ghozali, 2004: 17), or as much as 5-10 times the number of parameters estimated (Ferdinand, 2006: 44). In this study, the number of respondents of 800 taken from 8 Modern Market in Batam City with each 100 respondents, calculated by the formula Solvin, to Obtain as many as 266 respondents n. For Reviews These eligible to serve as a sample of 215 respondents.

$$
n=\left(\frac{\mathrm{N}}{1+\mathrm{N} \cdot d^{2}}\right)
$$

Information:

$\mathrm{n}=$ number of samples

$\mathrm{d}=$ Limit error $5 \%$

$\mathrm{N}=$ sample size

$$
\begin{aligned}
n & =\left(\frac{\mathrm{N}}{1+\mathrm{N} \cdot d^{2}}\right) \\
& =\left(\frac{800}{1+800 \times 0,05^{2}}\right) \\
& =266
\end{aligned}
$$

Based on the calculation results of the samples were at 266 but who returned the questionnaire only 215 respondents. Thus, the samples used in the study of 215 respondents.

\section{3) Research Instruments}

The primary instrument in this research was a questionnaire. Variable measurement is done by using the Likert scale. Measurement procedure as follows:

1. Respondents were asked to answer the common questions that will be used as the basis of Whether the respondents included in the criteria or not. 
2. Respondents were asked to agree or disagree with the statement filed by the researcher's perception of each respondent. The answer consists of five options items, namely: Strongly Disagree (SD), Disagree (D), Doubtful (Df), Agree (S), and Strongly Agree (SS).

3. Scoring. To answer Strongly Agree (SA) is assigned the value 5, and so on down to the answer of Strongly Disagree (SD) is given a score of 1.

Table: 1 Answer Scoring Quality of Respondents

\begin{tabular}{lll}
\hline \multicolumn{1}{c}{ Answer } & Score \\
\hline Disagree Strongly & 1 & \\
Disagree & 2 & \\
Doubtful & 3 \\
Agree & 4 \\
Agree strongly & 5 \\
\hline
\end{tabular}

\section{4) Data Collection Procedures}

The data used in the procedure of collecting the Data in this research consisted of primary the Data and secondary data. Primary data is the Data Obtained directly from the object of research items, namely by sending questionnaires directly to potential respondents.Data score of respondents' answers to any further processed with statistical indicators Full Model Structural Equation Modeling (SEM) using AMOS * software for Windows version 22.0 (Adi, (2015), Obtained was like the image display processing results Structural Equation Modeling (SEM) following. Conventional Bank (X1), Shariah Bank (X2), Customer Satisfaction $(\mathrm{Y})$ and Falah $(\mathrm{Z})$ as the following equation

H1: $\mathrm{Y}=\gamma_{\mathrm{y} \times \mathrm{x}} \mathrm{X} 1+\mathrm{e} 1, \rightarrow$ Direct Effects X1 to $\mathrm{Y}$,

$\mathrm{H} 2: \mathrm{Y}=\gamma_{\mathrm{y} . \mathrm{x} 2} \mathrm{X} 2+\mathrm{e} 1, \rightarrow$ Direct Effects $\mathrm{X} 2$ to $\mathrm{Y}$,

H3: $Z=\gamma_{z . \times 1} X 1+$ e2, $\rightarrow$ Direct Effects X1 to Z,

H4: $Z=\gamma_{z . x 2} X 2+$ e2, $\rightarrow$ Direct Effects X2 to $Z$,

H5: $Z=\beta$ zyY1 + e2, $\rightarrow$ Direct Effects $Y$ to $Z$

\section{5) Data Analysis Method}

Data analysis was performed using Structural Equation Model (SEM). The software used for the structural analysis is AMOS $22 *$. There are seven steps Involved in modeling SEM* items, namely:

1. Model-based development theory

2. Making the flow diagram (path diagram)

3. Convert flowchart into a series of structural equation

4. Selection of the input matrix and estimation techniques of models built

5. Assess possible problems of identification

6. Evaluation criteria for goodness of fit

7. Interpretation and modification of the models

Implementation of nature, this study uses the type or shape tools descriptive research conducted through the collection of field data. Descriptive research is the kind of research that describes what was done by the Department of Investment and Integrated Services One Stop based on the facts that there are to be further processed data. The data is then analyzed to derive a conclusion. Descriptive research is used to describe how each variable of the study. Qualitative methods, i.e., data processing methods that describe influences and relations expressed by the sentence. Qualitative analysis is used to look at the causes. The steps performed in Quantitative research is as follows: 
An Each indicator assessed by the respondents, classified in five alternative answers using the ordinal scale which describe rank answers.

b. I calculate the total score of each variable/sub variable $=$ overall score of all indicator variables for all respondents.

c. Inhitungskor each variable $/$ subvariable $=$ Average ratadaritotalskor.

d. For describes the respondent's answer, also used descriptive statistics such as frequency distribution and display in the form table or any graph.

e. For answered a description of each variable of this study, used span the following assessment criteria:

Table 2.

\begin{tabular}{l} 
Score Total $=\frac{\text { Actual score }}{\text { Ideal score }} \quad \mathbf{X 1 0 0 \%}$ \\
Score Total $=\frac{\text { Actual score }}{\text { Ideal score }} \quad X 100 \%$ \\
\hline
\end{tabular}

(Sumber: Narimawati, 2010: 45)

Skor actual all respondents answer on been proposed. Ideal score is the score or the highest weight, or all respondents assumed to choose the answer with the highest score. Descriptive analysis is performed referring to each indicator in each of the variables studied regarding the following table:

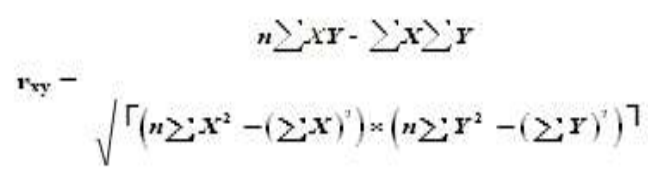

Table 3.

Classification Percentage of Respondents

\begin{tabular}{ccc}
\hline $\mathbf{N}$ & \%Score & Criteri \\
\hline 1 & $20.00 \%-36.00 \%$ & Very bad \\
2 & $36.01 \%-52.00 \%$ & bad \\
3 & $52.01 \%-68.00 \%$ & Pretty good \\
4 & $68.01 \%-84.00 \%$ & Good \\
5 & $84.01 \%-100 \%$ & Very good \\
\hline \multicolumn{3}{c}{ Source: (Narimawati, 2007: 85$)$}
\end{tabular}

\section{RESULTS AND DISCUSSION}

\section{a. Object of Research}

Batam Island was first inhabited by the Malays as the strait people since the year 231 $\mathrm{AD}$. The island that once served as the field of struggle of Admiral Hang Nadim against the invaders was used by the government in the 1960s as a petroleum logistics base on Sambu Island. In the 1970s, with the initial goal of making Batam Indonesia as Singapore, according to Presidential Decree number 41 year 1973, Batam Island is designated as working environment of industrial area supported by Batam Island Industrial Development Authority or better known as Batam Authority Body (BOB) as the driving force for the development of 
Batam. Nowadays the Agency of Batam (BP Batam). With the rapid development of the island of Batam, in the 1980s, based on Government Regulation No. 34 of 1983, the sub-district of Batam, which is part of the Riau Islands District, was upgraded to Batam municipality with the task of running government administration and society and support the development of Batam Authority (BP Batam). In the era of reform in the late 1990s, with Law No. 53 of 1999, Batam administrative municipality changed its status to an autonomous region, namely the Batam City Government to carry out government and development functions by involving the Batam Authority Body (BP Batam). The city, which is part of the province of Riau Islands, has a land area of $715 \mathrm{~km}^{2}$, while the total area reaches $1,575 \mathrm{~km}^{2}$.

Batam City has tropical climate with average temperature 26 to 34 degree celsius. The city has a hilly and deserted plain. The soil is a red soil that is less fertile and the weather is often changed so that to be used as agricultural land only plants that can grow without following the seasonIndonesia Free Trade Zone is a policy that has been established by the Government of Indonesia and implemented by BP Batam (Batam Enterprises Agency) into Free Trade Zone and Free Port where port in Batam City, Regency of Bintan and Regency of Karimun have permission tax-exempt of import-export goods valid from 1 April 2009 by the Minister of Finance and Minister of Trade. This makes electronic goods in Batam City or vehicles exempt from VAT, and causing electronic goods to be exit from Batam subject to Additional Taxes, as well as cars that were purchased not paid VAT, can not be brought out Batam, before paying 10\% VAT. Free trade in Batam City has encouraged the growth and development of modern market which is based on conventional marketing, this condition is certainly not in accordance with the vision of Batam City as a Madani World. In order to achieve a civil economy can only be obtained by multiplying the sharia market with shariabased marketing, to be held research on how big the role of sharia marketing in the city of Batam in the midst of the modern market.(Wikipedia, 2017).

\section{a. Research Result}

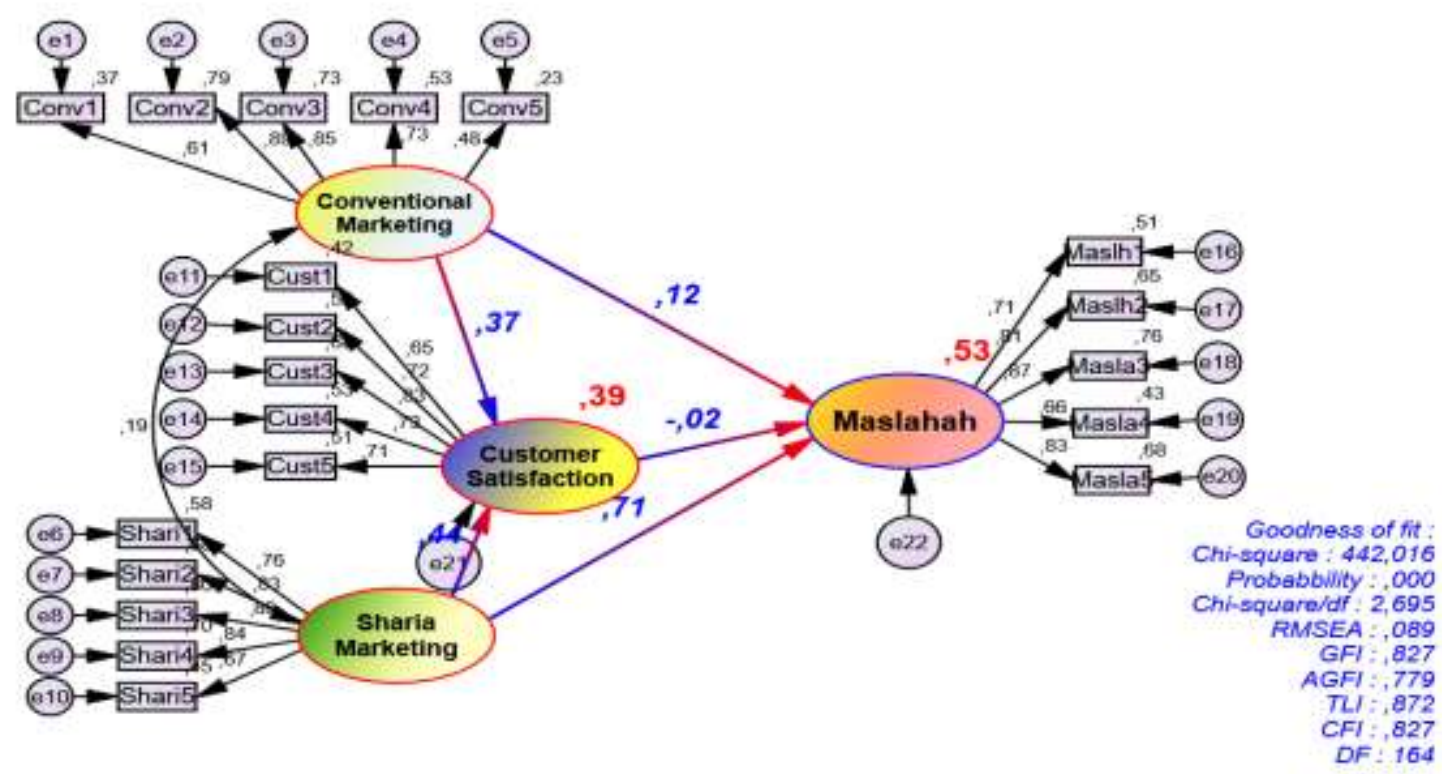

COMPARATIVE OF CONVENTIONAL MARKETING AND SHARIA MARKETING

AGAINST MASLAHAH WITH CUSTOMER SATISFACTION AS INTERVENING AT CUSTOMER MALL IN BATAM CITY - INDONESIA

Figure 3. Full Model 
Table 4.Regression Weights: (Group number 1 - Default model)

\begin{tabular}{llllllll}
\hline & & & estimate & SE & CR & P & Label \\
\hline CUST & $<---$ & Shar &, 299 &, 054 & 5,577 & $* * *$ & par_17 \\
CUST & $<---$ & CONV &, 247 &, 054 & 4,577 & $* * *$ & par_22 \\
LAHAH & $<---$ & CONV &, 100 &, 057 & 1,761 &, 078 & par_1 \\
LAHAH & $<---$ & CUST &,- 024 &, 100 &,- 244 &, 807 & par_2 \\
LAHAH & $<---$ & Shar &, 597 &, 079 & 7,576 & $* * *$ & par_3 \\
\hline
\end{tabular}

Table 5.Standardized Regression Weights: (Group number 1 - Default model)

\begin{tabular}{llll}
\hline & & & estimate \\
\hline CUST & $<---$ & Shar &, 443 \\
\hline CUST & $<---$ & CONV &, 368 \\
LAHAH & $<---$ & CONV &, 120 \\
LAHAH & $<---$ & CUST &,- 020 \\
LAHAH & $<---$ & Shar &, 710 \\
\hline
\end{tabular}

Table 6 Squared Multiple Correlations: (Group number 1 - Default model)

\begin{tabular}{ll}
\hline & estimate \\
\hline CUST &, 395 \\
LAHAH &, 535
\end{tabular}

\begin{tabular}{llll}
\hline Goodness of Fit Index & Cut-Off Value & Model Results & information \\
\hline Chi-square & Expected To Be Small & 442016 & Good \\
Relative Chi-square & $\leq 3: 00$ & 2,695 & Good \\
Probability & $>0.05$ & 0,00 & Not Good \\
RMSEA & $\leq 0: 08$ & 0089 & Marginal \\
GFI & $\geq 0.90$ & 0827 & Marginal \\
AGFI & $\geq 0.90$ & 0779 & Marginal \\
CFI & $\geq 0.95$ & 0835 & Not Good \\
TLI & $\geq 0.95$ & .869 & Marginal
\end{tabular}

Observing the cut-of-value and goodness of fit of model results shown in Table 5 , it shows only three criteria fulfilled and there are four marginals and one that is less good than the eight criteria used. Criteria fulfilled is Chi-square $\left(\chi^{2}\right)$ Relatitive Chi-square $\left(\chi^{2} / \mathrm{df}\right)$, which is marginal RMSEA,GFI, AGFI, and TLI, Probability and CFI is not good. Because there are two criteria are fulfilled and four marginals of the eight criteria required, then the above model can be expressed as a good model (Solimun, 2004: 71)

\section{b. Discussion}

a) Conventional variable effects on the variable Customer Satisfaction Marketing has standardized estimate (regression weight) of 0368 to $\mathrm{Cr}$ (Critical ratio $=$ identical to the value of t-test) of 4,577 on probability $=4,577 * * *$ Rated CR $\geq 2: 00$ and Probability $=* * * \leq 0: 05$ indicates that the Securities variable to variable Conventional Marketing Customer Satisfaction is significantly positive. Research by the theory that: more and more consumers have an alternative and very careful in Determining the decision to purchase to Consider Reviews These factors needs, product excellence, service and price comparisons before Deciding to buy. Of Reviews, These factors, the 
superiority of the products included in the main consideration before buying, so that a significant positive effect.

b) Sharia variable effects on the variable Customer Satisfaction Marketing has standardized estimate (regression weight) of 0443 to $\mathrm{Cr}$ (Critical ratio $=$ identical to the value $t$ count) equal to the probability $=5577,5577 \mathrm{CR} 449$ value $\geq 2: 00$ and Probability $=* * * \leq 0: 05$ indicates that the Securities variable to variable Sharia Customer Satisfaction Marketing is Significantly positive. In carrying out Shariahbased marketing cannot be separated from the law of Sharia law itself was called maqashid al-shari'ah consists of two words, maqashid and Shari'ah. Said maqashid a form jama 'of maqshad meaningful goals and objectives, while Shari'ah had understanding God's laws are set to man in order to be guided to ATTAIN happiness in this world and in the life hereafter. And thus, the maqashid al-Shari ' ah means the content of value into law shari'a goal. And thus, the maqashid al-Shari'ah are the objectives to be Achieved from a determination of the law, so that a significant positive effect

c) Securities Customer Satisfaction variable to variable Maslahah have standardized estimate (regression weight) of -0020 with $\mathrm{Cr}$ (Critical ratio $=$ identical to the value of t-test) of -0244 on probability $=0807,-0244 \mathrm{CR}$ value $\leq 2: 00$ and Probability $=0807$ $\geq 0: 05$ indicates that the Exchange Customer Satisfaction variable to variable is not significant Maslahah negative. In conventional marketing approach, marketing strategy formulation to emphasize narrative compelling ads and Often use words exploitative and exaggerated than the reality, the which plunge marketing Eventually rigid standards, and dried to innovation, so that the negative effect is not significant

d) Marketing Conventional variable effects on the variable Maslahah have standardized estimate (regression weight) of 0.120 to $\mathrm{Cr}$ (Critical ratio $=$ identical to the value of $\mathrm{t}$ test) of 1,761 on probability $=0.0781761 \mathrm{CR}$ value $\leq 2: 00$ and $0: 05 \geq$ Probability $=$ 0.078 indicate that the Securities Marketing Conventional variable to variable positive Maslahah is not significant. In conventional power marketing in general on promotion, is a form of marketing communication is a marketing activity that seeks to disseminate information, influence / persuade, and / or warned target market for the company and its products to be willing to accept, purchase, and loyal to the products offered by the company concerned, , so that the positive effect is not significant

e) Marketing Sharia variable effects on the variable Maslahah have standardized estimate (regression weight) of 0710 to $\mathrm{Cr}$ (Critical ratio $=$ identical to the value of t-test) of 7576 on a probability $=7,576 * * * \mathrm{CR}$ value $\geq 2: 00$ and Probability $=* * * \leq 0: 05$ indicates that the Exchange Sharia variable to variable Maslahah Marketing is a significant positive. Maslahah is something that is Able to provide convenience and support to guarantee the existence of each of the six major issues that are at the level hâjiyyâtmaslahah. Something that can give beauty, perfection, optimization to guarantee the existence of each of the six major issues that are at the level maslahah luxuries. Maslahah it includes two (2) elements of a coherent and holistic items, namely jalb al-manâfi '/ al-masâlihwadar al-mafâsid / al-madârr the which means " making something useful / good or bring benefit / goodness, and Prevent and Eliminate anything negative-destructive or bring damage / harm, in the which case all Werner within the framework of directives of the Qur'an and Hadith. In this case, need to be Considered regarding the concerns of individual interest / limited (almaslahah al-khâssah) and public interest/public (al-maslahah al-'amma), and priority is given to public interest / general people so that a significant positive effect.

a) Square Multiple Correlation for Customer Satisfaction $=0$, 395, To Maslahah $=0,535$ Square Multiple Correlation value for the variable Customer Satisfaction R2 $=0,395$ 
R2 is identical with the SPSS by 0, 395 then the magnitude Exchange Square Multiple Correlation is a value to a variable Customer Satisfaction times 100\% $=0,395 \times 100 \%$ $=39.50 \%$. Tus it can be stated that the change in Customer Satisfaction is influenced by Sharia Conventional Marketing and Marketing of 39.50\%. To Maslahah R2 = 0, 535 then the magnitude of the Securities Maslahah $=0,535 \times 100 \%=53.50 \%$. Tus it can be stated that the change is affected by the effects Maslahah Conventional Marketing and Sharia Marketing and amounted to 53,50\% customer satisfaction. Show if all done with Sharia Marketing model then InshaAllah number 53.50\% increased close to $100 \%$. Wallahu'lambishshowab.

\section{CONCLUSION AND SUGGESTION}

\section{a. Conclusion}

a) Marketing Conventional variable effects on the variable Customer Satisfaction is Significantly positive.

b) Marketing Sharia variable effects on the variable Customer Satisfaction is Significantly positive.

c) Customer Satisfaction variable effect on the variable is not significant Maslahah negative.

d) Conventional variable effects Maslahab Marketing variable is not significantly positive

e) Marketing Sharia variable effect on the variable is positive Significantly Maslahah

f) Changes in Customer Satisfaction is influenced by Sharia Conventional Marketing and Marketing of $39.50 \%$, while changes Maslabah is affected by the effects of conventional and Sharia Marketing and amounted to 53,50\% customer satisfaction.

\section{b. Suggestion}

a) Conventional marketing customers are satisfied because of their consumption consumptive (capitalist) views, material satisfaction alone so as not to have a significant effect on maslahah, therefore customers need to be enlightened by understanding the consumption of Islami

b) In order for Sharia Marketing Variables to Customer Satisfaction variable always positive significant, customer and pedagan need to be improved understanding that what is taught by Islam in marketing and consumption will always have maslahah effect that is satisfaction with material and spiritual dimension.

c) Customer Satisfaction to the maslahah variable is negatively insignificant, the proof of economic theory which states that humans are unsatisfied creatures. So consumers and traders not to sell products that just satisfy the appetite of consumption, but need to sell products that are useful for the establishment of worship.

d) Conventional marketing to the maslahah variable is positive is not significant, it is suggested that the marketing to sell products to the community with berorentasiSharia because it is Sharia that will deliver reach maslahah

e) Sharia marketing to the variable maslahab is a significant positive, this is what the vision of Batam City as Bandar DuniaMadani will be realized if the degree of society reaches the degree of maslahah in the midst of Free Stretch

f) To improve the change in customer satisfaction is influenced by conventional marketing and Sharia marketing, so that the modern market and traditional markets are built on the model of Sharia market in the form of goods sold, how to sell, environment and transactions in Sharia. 
AL-MASHRAFIYAH: Jurnal Ekonomi, Keuangan dan Perbankan Syariah Volume 2, Nomor 1 April 2018

\section{REFERENCE}

Adi, Rasmen (2015), "Free Structural Equation Modeling with AMOS version 22", Undiknas Press, Denpasar

Asmawi (2014), "Conceptualizing Theories Maslabab" regards; Journal of Philosophy and Culture, Faculty of Sharia and Law UIN Jakarta

Boyd, Harper W., et al., (2000), Marketing Management, Second Edition, Erland, Jakarta

Black, JA, \& DJ Champion. (2001). "Methods and problems of social research," Bandung: Refika Aditama.

Cooper, R. Donald., And Pamela S. Schindler. (2003). Business research methods. Eight Edition. New York: Mc. Graw-Hill

Chan, W. (2006) "Employees' Perception of Service Quality As A Major Determinant Towards Customer Satisfaction Of A Property Management Company In Hong Kong." Thesis. University of Hong Kong, Pokfulam, Hong Kong SAR,

Engel, J; Blackwell, R. (2004 Consumer Behavior. Dryden Press Chicago Andi, Yogyakarta.

Ferdinand, AT (2006). Methods of management research. Semarang: BP UNDIP Ghozali, I. (2005). Application of multivariate analysis using SPSS. Semarang: Diponegoro University Publishers Agency.

Fatima (2015) "Sharia-Based Marketing Strategy For Traditional Retail Able To Compete With Modern Retail" Jurnal Manajemen Bisnis Indonesia Vol 1. No. 2Esa Unggul University

Fauzi, Yayan (2015). Marketing Management Maqasid Islamic Perspective, Scientific Journal of Islamic Economics Vol. 01 No. 03, STEBI Al Muhsin Yogyakarta

Ghozali, Priest (2004). "The Application Of Multivariate Analysis With SPSS." Semarang: Diponegoro University Publishers Agency

Hair, JF Jr, RE, Anderson, RL, Tatham, \& WC Black. (1998), "Multivariate analysis of the data." New Jersey: Prentice Hall, Inc.

Kotler, Philip (2001) "Principles of Marketing" volume 1, the publisher, Jakarta

Philip Kotler and Keller. 2007 "Marketing Management: Analysis, Planning, Implementation, and Control." First Edition. Publisher Prentice Hall, Salemba Four, Jakarta.

Ministry of Religious Affairs (2016) "Book Quran Tafsir," Publisher Widya Light - Jakarta

Narimawati.Umi, 2007. Research in Human Resource Management. Jakarta: Great Media.

Nurcholifah, Ita (2014) "Strategy Marketing Mix In Islamic Perspective" Journal of the equator Journal of Islamic Studies Volume 4 Number 1, the Institute of Research and Community Service (LP2M) of IAIN Pontianak

Stanton, William. (1996) "Principles of Marketing." Erland: Jakarta.

Sivadass, E., \& Baker-Prewitt, JL (2000). "An Examination of the Relationship between Service Quality, Customer Satisfaction, and Store Loyalty." International Journal of Retail \& Distribution Management, 28 (2), 73-82.

Solimun.(2004). "Multivariate Analysis Structural Equation Modeling (SEM) lisrel and AMOS". Malang: Faculty of Mathematics and Natural Sciences, Universitas Brawijaya

Hoses, Christian AD (2013) "Marketing Mix Influence on Consumer Loyalty In Fresh Mart Mall Manado Bahu," EMBA Journal Vol.1 3 June 71, 2013, p. 71-80, Faculty of Economics Department of Management, University of Sam Ratulangi, Manado

Tjiptono, Fandi (2007) "Sales Management Product." First Edition. Publisher Canisius, Yogyakarta. (2008) "Marketing Strategy." Edition III Andi, Yogyakarta.

Wibisono, Chablullah (2017) "Effects Rahn, Ljaroh, Customer Satisfaction Through Quality Of Service In. Pt. Sharia Rural Bank Reputable Madani ", ICoSTRD Proceeding ID.1313 2017, UTHM Makassar, Indonesia. 